\title{
Customer Satisfaction in Career Enhancement with the Usage of E-Learning Software
}

\author{
Gopinathan, S Praveen Kumar, Pothumani
}

\begin{abstract}
Showcasing has its source in the way that people are animals of necessities and needs. Since numerous items can fulfill a given need, item decision is guided by the ideas of significant worth, cost and fulfillment. These items are realistic in a few different ways; self-creation, pressure, asking and trade.
\end{abstract}

Promoting emerges from this last way to deal with obtaining items. The entire of promoting depends on the procedure of trade. Advertising thoroughly means working with business sectors to realize trade to fulfill human needs and needs. Association lifts its quality on its promoting approaches, which are the most fundamental piece of development and improvement of the association. In this unique circumstance, E-Learning Companies in Chennai is in the phase of reinforcing up its promoting capacities, along these lines making a need to grasp the effect of its arrangements on their customers. The task targets finding the effect of promoting approaches of E-Learning Companies towards its clients in Chennai city, which would go about as a venturing stone for the organization to spread the action to the whole nation.

Keywords: E-Learning Companies, generalizabilit discernments

\section{INTRODUCTION}

In the present seriously focused condition, organizations today are always searching for approaches to draw in clients by having a superior comprehension of changing client inclinations. To conquer any hindrance between hypothesis and practice and to develop legitimate personality and produce truly necessary spirit for example to assist the understudies with identifying their solid and frail focuses in the accompanying and acknowledging different authoritative exercises. [31],[33] With the goal that proper measures can be taken at a most punctual time. This exploration concentrate would be valuable to the administration of E-Learning Companies to comprehend the clients' desires and the assessment about programming items the respondents for this overview were understudies. Information investigation and understanding will be finished

Revised Manuscript Received on July 22, 2019.

Gopinathan, student, Department of MBA,Bharath institute of Higher Education \& Research,Tamilnadu ,India Email:gopinathan@ gmail.com

Dr. S Praveen Kumar Director Department of MBA, Bharath institute of Higher Education \& Research ,Tamilnadu ,India, Email: pavithralect@yahoo.com

Pothumani Assistant Professor, Department of CSE,Bharath institute of Higher Education \& Research ,Tamilnadu ,India,. Email: pothumani@gmail.com utilizing the gathered information with fundamental measurable devices, in light of the discoveries; recommendations will be given to the association. [1],[3],[5] Business extension comprises of different gathering of offers and limits; for the most part momentary intended to invigorate snappier and/or more noteworthy buy of a specific item by shoppers or the exchange. Deals advancement incorporates instruments for customer advancement (for instance tests, coupons, prizes, money discount, guarantees, shows, challenge); exchange advancement (for instance purchasing recompenses, free products, stock stipends, co-usable publicizing, promoting and show remittances, vendor deals challenges); and deals power advancement (for instance rewards, challenges, deals encourages). [2 ],[ 4],[6] As of late the idea of affirmation projects has gotten more prominent consideration among instructed individuals for getting advancements in their vocation and to overhaul their profile. E-Learning Companies., has been the market's driving player from time in giving preparing and affirmations to experts from crosswise over different businesses from everywhere throughout the world been it neighborhood or worldwide. E-Learning Companies is the unprejudiced and free outsider Conformance Assessment Body. It furnishes hesitant leaders with a motivating force to settle on decisions by expanding the worth offered by a specific brand. [7],[ 9], [11]

This exploration concentrate would be helpful to the concerned specialists of E-Learning Companies to comprehend the shoppers' discernment and their inclination for the accreditation courses which would make them to settle on extension of their business concentrating on ITI and Diploma holders. The respondents for this study were learners who are getting preparing from the organization and the individuals who finished the course as of late. Information investigation and translation will be finished utilizing the gathered information with essential measurable devices, in light of the discoveries; proposals will be given to the association. [8],[10],[12]

\section{RESULTS}

$13 \%$ respondents came to know about E-Learning Companies through marketing executives, $32 \%$ of them came to know through reference, $22 \%$ of them get to know E-Learning Companies from Internet, $20 \%$ of them came to know from newspapers and magazines and rest $13 \%$ said they came to know from other sources.7\% respondents strongly agree that support person gives the solution on time, $52 \%$ of them agree with this, $16 \%$ of the respondents are neutral towards this, $11 \%$ respondents disagree and rest $0 \%$ of them strongly disagree with this. $13 \%$ respondents strongly 
agree that E-Learning[26],[28],[30]

Companies need to do promote more about its certification, $67 \%$ of them agree with this, $13 \%$ of the respondents are neutral towards this, $7 \%$ respondents disagree and rest $0 \%$ of them strongly disagree with this. $15 \%$ respondents strongly agree that the course provided have positive impact on the career, $57 \%$ of them agree with this, $13 \%$ of the respondents are neutral towards this, $13 \%$ respondents disagree and rest $2 \%$ of them strongly disagree with this. $22 \%$ respondents are highly satisfied with the price for course at E-Learning Companies, $65 \%$ of them are satisfied, $11 \%$ of the respondents are neutral towards this, and $2 \%$ respondents are dissatisfied and rest $0 \%$ of them highly dissatisfied with this. $17 \%$ respondents are highly satisfied with the course syllabus at E-Learning Companies, $46 \%$ of them are satisfied, $20 \%$ of the respondents are neutral towards this, and $9 \%$ respondents are dissatisfied and rest $7 \%$ of them highly dissatisfied with this. $13 \%$ respondents are highly satisfied with the certification value of E-Learning Companies, $39 \%$ of them are satisfied, $33 \%$ of the respondents are neutral towards this, and $13 \%$ respondents are dissatisfied and rest $2 \%$ of them highly dissatisfied with this. $11 \%$ respondents said the overall services of E-Learning Companies are excellent, $30 \%$ of them said it is very good, $33 \%$ of the respondents said to be good, $22 \%$ respondents said the services are average and rest $4 \%$ of them said it is poor. [13], [15] , [ 17]

\section{CONCLUSION}

As far as the survey is concerned a good understanding of the training companies was done. The objectives of the project were fulfilled. The key conclusions from the report are: [19],[21],[23]

The study reveals that E-Learning Companies is trying its level best to increase its customer satisfaction. But there are some more steps are to be taken it improve further customer's satisfaction which is beneficial both for the customers and the company. The company should adopt the modern concept of marketing strategy which emphasizes that marketing which starts with consumers and ends with customers[14],[ 16], [18].

\section{REFERENCES}

1) BharthVajan R., Ramachandran S.,Psychographic dimensions of training,2016,International Journal of Pharmacy and Technology,V-8,I-4,P-23727-23729

2) Balakrishnan P., Bharthvajan R.,A study on human resource planning in hospitals in Chennai City,2014,International Journal of Applied Engineering Research,V-9,I-22,P-7503-7507

3) Priyadarsini P., Bharthvajan R.,Role of emotional intelligence training programme in reducing the stress of the nurses,2014,International Journal of Applied Engineering Research,V-9,I-22,P-7411-7421

4) Kerinab Beenu G., Bharthvajan R.,Empirical analysis on the cosmetic buying behavior of young women in South India,2014,International Journal of Applied Engineering Research,V-9,I-22,P-7361-7366

5) Balakrishnan P., Bharthvajan R.,Whistling in the wind,2014,International Journal of Applied Engineering Research,V-9,I-22,P-7586-7593

6) Krishnan B., Peter M.,Health hazards of Indian Bpo employee-an alarming issue,2014,International Journal of Applied Engineering Research,V-9,I-22,P-7336-7341

7) Kerinab Beenu G.H., Peter M.,Role of insurance in economic development,2014,International Journal of Applied Engineering Research,V-9,I-22,P-7532-7539
8) Balakrishnan P., Peter M., Priyadarsini P.,Efficiency of safety measures for wellbeing of employees in manufacturing industry,2014,International Journal of Applied Engineering Research,V-9,I-22,P-7376-7382

9) Anbarasi M., Praveen Kumar S.,Online sales promotions of herbal products and its effectiveness towards tanisha.com,2019,Indian Journal of Public Health Research and Development,V-10,I-1,P-195-200

10) Anbarasi M., Praveen Kumar S.,Various online marketing and promotions strategies to improve the validation towards the organic products in the pharmaceutical sectors,2019,Indian Journal of Public Health Research and Development,V-10,I-1,P-263-269

11) Loganathan R., Praveen Kumar S.,Grievance handling a key factor for solving issues of employees in an organization,2014,International Journal of Applied Engineering Research,V-9,I-22,P-7483-7491

12) Loganathan R., Praveen Kumar S.,Study on preference of private label brands in super and Hypermarkets,2014,International Journal of Applied Engineering Research,V-9,I-22,P-7327-7335

13) Smitha M., Praveen Kumar S.,Understanding stress and its managementamong the nurses in Chennai city,2014,International Journal of Applied Engineering Research,V-9,I-22,P-7560-7565

14) Kerinab Beenu G.H., Praveen Kumar S.,A study on the investment behavior of Chennai investors in mutual fund schemes,2014,International Journal of Applied Engineering Research,V-9,I-22,P-7520-7525

15) Loganathan R., Praveen Kumar S.,Retention strategies key for organizational productivity,2014,International Journal of Applied Engineering Research,V-9,I-22,P-7443-7447

16) Pavithra J., Ganesan M., Brindha G.,State wise analysis of microfinance sector in India,2016, International Journal of Pharmacy and Technology,V-8,I-4,P-23417-23432

17) Pavithra J., Ganesan M.,A comparative study on microfinance in India and abroad,2016,International Journal of Applied Business and Economic Research,V-14,I-8,P-5471-5476

18) Pavithra J., Ganesan M.,A study on awareness and impact of micro-financial schemes,2016,International Journal of Applied Business and Economic Research,V-14,I-8,P-5449-5460

19) Senthilmurugan P., Pavithra J.,Consumer preference towards organised retailing with reference to Big Bazaar,2014,International Journal of Applied Engineering Research,V-9,I-22,P-7469-7475

20) Senthilmurugan P., Pavithra J.,Implication of social media marketing in growing healthcare industry,2014,International Journal of Applied Engineering Research,V-9,I-22,P-7448-7456

21) Loganathan R., Pavithra J.,Consumer perception towards private label brand over other brands in super markets and hypermarkets,2014,International Journal of Applied Engineering Research,V-9,I-22,P-7355-7360

22) Kerinab Beenu G., Pavithra J.,Tradeâ€"off between liquidity and profitability in logistics industry,2014,International Journal of Applied Engineering Research,V-9,I-22,P-7398-7401

23) Kerinab Beenu G., Pavithra J.,A study on the prospective consumerâ€(M perception towards utility cars in Chennai city,2014,International Journal of Applied Engineering Research,V-9,I-22,P-7526-7531

24) Pavithra J., Dilli Babu P., Ambuli T.V.,A study on budgetary control at Maruti Service Masters, Chennai,2014,International Journal of Applied Business and Economic Research,V-12,I-2,P-151-161

25) Pavithra J., Dilli Babu P., Ambuli T.V.,A study on customer satisfaction of retro Garments Pvt Ltd, Chennai,2014,International Journal of Applied Business and Economic Research,V-12,I-2,P-381-391

26) Kerinab Beenu G.H., Pavithra J., Senthilmurugan P.,A study on the influence of promotional activities for TATA ARIA among consumers in Chennai,2014,International Journal of Applied Engineering Research,V-9,I-22,P-7572-7578

27) Vijayaragavan S.P.,An investigative expert that's general FBG sensors,International Journal of Mechanical Engineering and Technology,V-8,I-8,PP-1500-1505,Y-2017

28) Vijayaragavan S.P.,Equalization routing protocol for Wi-Fi sensor strategy,International Journal of Mechanical Engineering and Technology,V-8,I-8,PP-1662-1666,Y-2017

29) Karthik B., Kiran Kumar T.V.U., Vijayaragavan P., Bharath Kumaran E.,Design of a digital PLL using 0.35 $\hat{\mathrm{I}}^{1 / 4 \mathrm{~m}}$ CMOS technology,Middle East Journal of Scientific Research,V-18,I-12,PP-1803-1806,Y-2013

30) Kanniga E., Selvaramarathnam K., Sundararajan M.,Kandigital bike operating system,Middle - East Journal of Scientific Research,V

31) Jasmin M., Vigneshwaran T. Beulah Hemalatha S.,Design of 
power aware on chip embedded memory based FSM encoding in FPGA,International Journal of Applied Engineering Research,V-10,I-2,PP-4487-4496,Y-2015

32) Jasmin M.,Optimization techniques for low power VLSI circuits,Middle East Journal of Scientific Research,V-20,I-9,PP-1082-1087,Y-2014

33) Jasmin M., Vigneswaran T.,Fuzzy controller for error control of on - Chip communication,2017 International Conference on Algorithms, Methodology, Models and Applications in Emerging Technologies, ICAMMAET 2017,V-2017-January,I-,PP-1-5,Y-2017

\section{AUTHORS PROFILE}

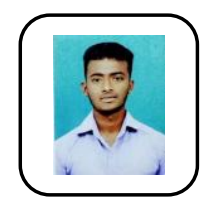

Gopinathan, student, Department of MBA,Bharath institute of Higher Education \& Research ,Tamilnadu ,India

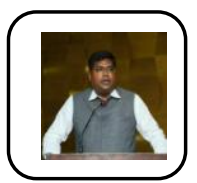

Dr. S Praveen Kumar Director Department of MBA Bharath institute of Higher Education \& Research ,Tamilnadu ,India,

Pothumani Assistant Professor, Department of CSE,Bharath institute of Higher Education \& Research ,Tamilnadu ,India 